Published as: TIMBERLAKE, M., M.R. SANDERSON, X. MA, B. DERUDDER, J. WINITSKY \& F. WITLOX (2012) "Testing a global city hypothesis: an assessment of polarization across U.S. Cities". City \& Community. Vol. $11(1)$, pp. 74-93

\title{
Testing a Global City Hypothesis: An Assessment of Polarization across U.S. Cities
}

Michael Timberlake*

University of Utah

Matthew R. Sanderson

Kansas State University

Xiulian Ma

Chinese Academy of Governance

Ben Derudder

Universiteit Gent

Jessica Winitsky

University of Utah

Frank Witlox

Universiteit Gent

*Michael Timberlake, Department of Sociology, University of Utah, 380 S 1530 East, Room 301, Salt Lake City, UT 84112 timber@ soc.utah.edu

\section{Running Head: Globalization, Cities, and Polarization}




\section{Testing a Global City Hypothesis: An Assessment of Polarization across U.S. Cities}

Social polarization is perhaps most evident within the world's large cities where we can easily and often observe stark contrasts between wealth and poverty. A "world city" theoretical perspective has emerged that associates large cities' importance in a global network of cities to the degree of internal polarization within these cities. The research reported here locates 57 large U.S. cities within this world city hierarchy and then empirically examines the hypothesized positive association between global centrality and social polarization using a multivariate, crosscity analysis. The findings are mixed, with some evidence that global centrality increases income polarization, but only in the context of higher levels of immigration. There is no evidence that a city's centrality affects occupational polarization. We conclude by suggesting implications for the world city literature and future research. 


\section{Testing a World City Hypothesis:}

\section{Does the Location of U.S. Cities in the World System of Cities Explain Levels of Social Polarization within Them?}

\section{Introduction}

In 1986, John Friedmann published "The World City Hypothesis", an article in which he elaborated on the concept of world cities and put forth seven assertions about the relationship between the world's large cities and globalization. This seminal article served to crystallize a line of inquiry that had begun several years earlier but since then has flourished in social science theory and empirical research. Scholars working on cities and globalization have subsequently concentrated on this "world city" concept (Friedmann, 1986) and the related one of "global cities" (Sassen, 2001).

From the perspectives embedding these concepts, organizational ties across cities (e.g., headquarters and back offices) and the flows of capital, information, and people between cities have interconnected the world's great cities (Friedmann, 1986, 1995, 2001; Sassen, 1991, 2001; Taylor, et al. 2002). The most pivotal world cities in this network are followed by less central cities that, nevertheless, articulate among large regions of the world economy. The image that emerges from this body of scholarship is that of a hierarchical world-system of cities (see Knox and Taylor, 1995; Taylor, et al., 2011). From its inception, world city research has focused on identifying this network of global cities and relating it to processes of global transformation since the late $20^{\text {th }}$ Century. While the conceptual work on world cities and global cities is rife with hypotheses and case-based observations on the social-structural concomitants of a city's place in the global network, globalization scholars have been reluctant to engage in systematic research 
on how cities' global centrality positioning affects the social structures within them. This paper fills this lacuna by exploring one of the key claims about global cities: the claim that, by virtue of their hierarchical place in the global system of cities, cities nearer "the top" of the hierarchy are, correspondingly, more socially polarized.

\section{From Mapping the Network to the Effects of Network Position}

Locating cities in the global network. Since about 1995, world city scholarship has included an increasing number of empirical representations of the world city hierarchy, most of which are based on relational data linking cities through various flows between pairs of cities or through the organizations sited in those cities (e.g., Smith and Timberlake 1995, 2001; Taylor and his associates in the Globalization and World City [GaWC] research network [e.g., Derudder et al., 2003; Taylor 2004]; Alderson and Beckfield 2004; Derudder and Witlox 2005; Derudder et al. 2010). This body of work has located specific cities within global networks of cities, usually identifying cities by their degree of centrality in the network at a particular point in time.

More recent research has become more nuanced. Today we have studies that show how cities' relative positions in the network change over time (Smith and Timberlake 2001), studies that focus on the degree of integration within the global city system and changes therein (Taylor, et al, 2011), and studies that analyze the extent to which the global city system has become independent of the system of nations in which the cities are located (Alderson, et al., 2010; Mahutga, et al, 2010). The research reported here uses one global city mapping procedure to assign "global centrality" scores to cities.

Consequences of World City Network Location. In his seminal piece on the world city hypothesis, Friedmann connected cities' locations in the global hierarchy of cities to social 
patterns within cities. He very clearly articulated that social outcomes within cities were related to cities' positions within the global hierarchy of cities:

"1. The form and extent of a city's integration into the world economy, and the functions assigned to the city in the new spatial division of labour, will be decisive for any structural changes occurring within it" (1986: 70).

Friedmann also expected that cities that were more central to the global system would be more socially polarized:

"6. World city formation brings into focus the major contradictions of industrial capitalism--among them spatial and class polarization" (1986:76).

Sassen $(2001,2006)$, too, expects that cities' social structures will depend on the nature of their role in a global network of urban places. In much of her writings on globalization, her focus is on the "global cities" at the very top of the hierarchy. These are the global control centers of the international economy in which, she argues, social polarization is especially pronounced. However, she also argues for similar, but less pronounced, tendencies farther down the global city hierarchy (Sassen, 2008: 477; 2009: 54).

The purpose of this paper is to empirically assess these claims by examining data on large U.S. cities in 2000. We first review the literature bearing on global cities and polarization. Then we describe the data that this paper brings to bear on the matter, followed by a presentation of 
the data analysis. We end by discussing the implications of our findings relative to the specific hypotheses as well as the larger literature.

\section{Literature review: polarization and professionalization in world cities}

\section{Polarization}

For both Sassen and Friedmann the mechanisms that link cities' global centrality to polarization emanate from structural concomitants of the economic roles that they play in the world economy. Class polarization in these cities is characterized by "large income gaps between transnational elites and low-skilled workers, large-scale immigration from rural areas or abroad, and structural trends in the evolution of jobs" (Friedmann, 1986: 72). In cities atop the world city hierarchy, production (in both manufacturing and producer services) is more capital intensive, leading to "an ecology of jobs" defined by small (but growing) high wage professional, technical, and managerial workers (largely in producer services) and the “destruction of jobs in the high wage unionized sectors" (1986: 77). High wage professional occupation growth creates demand for low-wage jobs in consumer and personal services-jobs often filled by women and immigrants.

Similarly, Sassen $(1988,2001,2006)$ argues that key globalization processes, including global economic restructuring and international migration, fuel social polarization. First, the rise of producer service industries as the leading edge of the global economy has created an increasing proportion of very-high-income positions in top global cities, while also generating more demand for low-wage workers. At the same time, manufacturing has been spatially 
decoupled from leading cities in core nations, resulting in a decline in relatively well-paid, lowskilled and semi-skilled jobs in this sector (Sassen, 1991, pp. 197-319). The increasing numbers of workers in producer services requires "an army of low-wage workers" (Sassen 1985: 262). These workers fill an astonishing array of jobs, including "residential building attendants, dogwalkers, housekeepers for the two-career families, workers in the gourmet restaurants and food shops, French hand laundries, and so on" (Sassen 1985: 262). Because these low-skilled jobs are often filled informally, they attract immigrants, many of whom lack the documentation necessary to acquire formal sector employment. Thus, a key feature of globalization is manifested disproportionally in more globally central cities, which are home to capital-intensive firms, as a growing high-income service sector exists alongside an expanding low-income service sector, with little growth in the middle of the income distribution. Sassen argues that there is "...a dynamic of valorization at work that has sharply increased the distance between the devalorized and the valorized—indeed the overvalorized—sectors of the economy" (2007: 109-10), producing global cities that are highly polarized in terms job opportunities, incomes, skill levels, and housing patterns.

Sassen (1985) claims that the expansion in the number of low-wage jobs in the manufacturing sector is due to three important factors: 1) "the social reorganization of the work process, notably the expansion of sweatshops and industrial homework; 2) the technical transformation of the work process that has induced a downgrading of a variety of jobs; and 3) the rapid growth of high technology industries that are characterized by a large share of lowwage jobs in production" (262-263). Again, these processes are more extreme in more globally central cities due to their roles as loci of global power and control. 
Hamnett (1994) disagrees with some of Sassen's contentions (see below), but he broadly agrees on the topic of polarization. He states that the downgrading of the manufacturing sector has led to a decline in unionized shops. In addition, "wages deteriorate while sweatshops and industrial homework proliferate" (404). Some of the aspects of globalization that scholars see as contributing to polarization include the rise of information technology, the absence of institutional regulations, and the rise of informal sectors in cities like London and New York (e.g., Levine, 1995; Burgers and Musterd, 2002, Savitch, 2002; Cox and Watt, 2002; Vaattovaara and Kortteinen, 2003). Although a voluminous research literature exists on the topic of increasing socioeconomic polarization in advanced national economies (see also Alderson and Neilson, 2002; Autor, et al., 2006: 191; Lemieux, 2008; and Goos, et al. 2009), very little of it focuses on "world cities" in particular.

\section{Professionalization}

The world city-polarization hypothesis first developed by Friedmann and then further elaborated by Sassen has attracted a fair amount of criticism in recent years. Hamnett (1994, 1996) argues that "polarization" remains conceptually underdeveloped in the literature and that, while occupational polarization may be occurring in some global cities, the more significant secular occupational trend in Western urban economies is professionalization. Hamnett and others also accuse Sassen of overgeneralizing from tendencies in primarily American cities, and others underline this critique, pointing out that many specific historical, cultural, and political conditions are more important in shaping the nature and degree of polarization across the world's 
major cities (e.g., Abu-Lughod, 1999; Hamnett, 1996; Hill 2000; Hill and Fujita 200; Bergers and Musterd, 2002).

Empirically, Nørgaard (2003) and Hamnett (1994) have found evidence refuting Sassen’s polarization theory. Nørgaard examined the New York metropolitan area and found that "the employment structure... has become more similar to other areas in the United States in the period between 1970 and 1990” (115). Specifically, “while wages are clearly distributed very unevenly this pattern of inequality was already established by the beginning of the study period" (115). Nørgaard asserts that the specialization in producer services that Sassen claims has occurred in global cities like New York does not have an empirical basis. Instead, Nørgaard found evidence of a trend toward more generalized job structures, a transformation that is hardly confined to the most globally central cities.

In spite of such important critiques of the world city-polarization thesis, the matter has hardly been settled. It seems to us that the real tension in Friedmann's and Sassen's arguments that empirical research can should begin to address is whether cities higher up in the global hierarchy of urban places are different with respect to social polarization in the ways the thesis suggests than cities lower in the hierarchy. Testing this thesis suggests a comparison of cities along a continuous measure of position in the global urban hierarchy.

This is not to say that critics' objections to the world city-polarization thesis are not valid. First, we would be surprised if culture, history, and politics did not affect forms of polarization in cities. Second, the "professionalization" objection to the thesis needs to be more seriously considered empirically. The global economy could really be generating more equitable employment opportunities, on average, across the world city hierarchy. Finally, there are plenty 
of reasonable people, scholars and pundits alike, who would argue that the polarizing effects of globalization are ubiquitous, not at all confined to the top levels of the global city hierarchy. If so, we would not expect to see evidence that polarization varies with the degree of cities' global centrality. Thus, the fundamental question remains: does position in the global urban hierarchy contribute to an explanation of polarization within urban places?

An important theoretical wrinkle in the world city-polarization argument bears upon the significance afforded by scholars such as Sassen to the role of immigration in the processes of global city formation. For Sassen $(1988,2001)$, immigrants constitute a global labor supply system that arises from a set of global dynamics that push migrants from less-developed countries and pull them toward developed countries, and specifically toward global cities. On the push side, structural adjustment policies and global capital flows in less-developed countries generate conditions that exacerbate emigration; they tend to displace traditional forms of production, feminize the labor force, and uproot large segments of the population while laying the organizational and institutional infrastructures that facilitate the international movement of labor. On the pull side, the growth of advanced producer services in developed countries, the downgrading of the manufacturing sector and the casualization and informalization of employment have produced a significant demand for low-wage labor, which has been filled predominately with immigrant labor. Although the push and pull dynamics promoting international migration are typically considered to be analytically distinct, Sassen treats them more holistically, contending that they are both associated with an integrated process of global economic restructuring: "The same set of basic processes that has promoted emigration from several rapidly industrializing countries has also promoted immigration into several booming 
global cities" (Sassen 1988: 22). Recent work has found empirical support for her arguments linking emigration from less-developed countries to economic globalization (Sanderson and Kentor 2009; Sanderson and Kentor, 2008).

Indeed, there is strong theoretical rationale for believing that the effect of a city's global embeddedness on polarization will depend on the extent of immigration into a city. At the most basic level, immigrant workers are useful to global city employers because the ways of controlling them are much simpler, cheaper and more straightforward than with other groups. Sassen (1988: 42) asserts:

Immigrants, especially in the United States, are often employed in firms where the system of control rests not on techniques of production and elaborate organizational arrangements, but on the powerlessness of the workers. Control is not structural, but immediate and personal. Employers can respond to workers' dissatisfaction, complaints, and rebellion by firing them. Given these means of controlling workers, the powerlessness of immigrants is particularly significant.

Of course, this applies to immigrants in low skilled occupations who are less likely to be fully documented and less likely, initially, to be fluent in English (for U.S. cities).

More broadly, higher levels of immigration might exacerbate the polarizing effects of global centrality because the expansion of the high-skill service sector, so characteristic of social structures in global cities, is predicated on a sufficient supply of low-skill labor, which is most often fulfilled through immigration. Indeed, the growth of these two labor markets is 
intrinsically linked, as both advanced producer service firms and their employees' consumption patterns generate strong demand for low-wage service labor:

The expansion of the high-income workforce in conjunction with the emergence of new lifestyles have led to a process of high-income gentrification that rests, in the last analysis, on the availability of a vast supply of low-wage workers... All of these trends give these cities an increasingly sharp tendency toward social polarization (Sassen 2008: 481).

\section{Methodology}

Ideally, we would conduct our analysis on major cities in the world as a whole. However, the city-level data for many of the variables necessary to test this hypothesis across cities in most of the world's countries are not readily available. There are advantages, however, to restricting the analysis to cities within one country. The most significant of these advantages has to do with the effects that national policies (e.g., taxation and income redistribution policies) are likely to have on the degree of polarization of cities. If we had an international dataset, we would certainly need to control for variation in these nation-level differences. With data from only one nation, this problem is eliminated, as all of the cities in our dataset share the same national policy context. Of course there may be some variation in state and local policies that affect income distributions directly, but probably only in very minor ways compared to national level policies. We also note that, in studying U.S. cities alone, we are considering only cities in the core of the world-system so we do not need to control for variation in world-system position. 
This is important since previous research has shown that world-system processes contribute to different income distribution patterns across nations (Alderson and Nielsen, 1999).

Much of our data come from the U.S. Census 2000. The data are available at various levels of agglomeration. We use "urbanized areas" because they are the geographic units within which urban social polarization occurs. That is, polarization is replicated within urbanized areas, not within (say) city limits. It is also the unit that the Census uses to make much of our data available, in contrast to metropolitan areas. We restricted the analysis to large, urban areas with populations that exceeded 750,000 in 2000. Thus, our dataset includes 57 cities.

Hypotheses. Following Sassen and other proponents of the global cities and world cities theses, we hypothesize that cities that are higher up in the global hierarchy of places - those more central to the global network of cities - will have higher levels of social polarization. Thus, we expect that our measure of centrality will have a positive effect on polarization.

We use two indicators of polarization: income polarization and occupational polarization. ${ }^{1}$ Using two indicators of polarization as outcomes in the analyses captures multiple dimensions of polarization, and allows us test the sensitivity of our findings to alternative measures. We note that polarization is conceptually distinct from overall inequality. Increasing overall inequality could occur as a result of a number of different redistribution patterns as long as three or more percentiles (or comparable) are involved in the calculation. Polarization, however, occurs when the relative sizes of both the high and low segments of the particular distribution are relatively large. While the world city literature does not always clearly distinguish between overall inequality and polarization, Sassen is quite clear that more globally 
central cities are polarized, especially in terms of increasing shares of the labor force at both the bottom and the top of the occupational ladder.

Data and Measures. The most theoretically interesting variable in our analyses is the global centrality of cities (GLOBAL). Measuring this concept involves estimating cities' relative positions in an urban hierarchy—a global urban hierarchy in this case. There is a long history of estimating the location of cities' in urban hierarchies, and until recently this was accomplished by comparing key attributes of cities that were assumed to be related to their "dominance" in a given system of cities. For example, population size of cities or the number of Fortune 500 headquarters sited in cities was used to measure a city's place in an urban hierarchy. However, for the past twenty-five years, researchers working on mapping the world-system's city system have increasingly turned to network analysis of relational data to accomplish the task (e.g., Smith and Timberlake, 1995a). This is hardly surprising since most theorizing about systems of cities has always been about network relations, but the methodological tools for modelling the actual networks have not been available until fairly recently. Now global city networks are routinely mapped with relational data using some form of network methodology, and the data employed include airline passenger flows (Smith and Timberlake, 1995a, 2001; Shin and Timberlake, 2000; Ma and Timberlake, 2008; Derudder and Witlox, 2005); intra-firm networks across cities (e.g., Taylor, et al. 2002, Alderson and Beckfield, 2004); internet backbone linkages (e.g., Vinciguerra, et al., 2010); and scientific collaborations linking researchers located in different places (e.g., Matthiessen, et al., 2010). In principle, many other sorts of relational data could be used, including commodity flows, migration flows, and 
telecommunication flows (cf., Smith and Timberlake, 1995b). However, so far, estimates for these other flows across cities are not available.

We use flows of air passengers travelling to and from other cities to generate our measure of global centrality. Operationalizing global centrality with air passenger flow data is well established in the literature. Our measure is derived from a unique data set that provides information on individual passenger flows in 2001. This so-called 'MIDT-database' is described in detail in Derudder and Witlox (2005), and reference should be made to this publication for further details. Here we only provide a brief summary of these data. This database has been used for a number of publications (e.g., Derudder and Witlox, 2008) on global city hierarchy and relative position of cities in the world system of cities and is similar to, but more inclusive than, the data set used by Smith and Timberlake (2001), which has also produced a number of complementary studies.

The MIDT database contains information on bookings made through Global Distribution Systems (GDS) such as Galileo, Sabre, Worldspan, Topas, Infini, Abaccus and Amadeus. GDS are electronic platforms used by travel agencies to manage airline bookings (i.e. the selling of seats on flights offered by different airlines), hotel reservations, and car rentals. Using a GDSbased database therefore implies that bookings made directly with an airline are often excluded from the system and therefore the data. However, in 1999, just two years prior to our data, $80 \%$ of all reservations continued to be made through GDS (Miller, 1999). Thus, although our information source may give a slightly biased picture of airline connections, there is no reason to assume that the overall pattern of reservations made by direct bookings differs fundamentally from that for reservations made through a GDS. 
The the MIDT database over other airline data sources (e.g., Smith and Timberlake, 2001) it contains actual origin/destination (O/D) information which minimizes the problem of overrating of the connectivity of airline hubs and first-tier world cities is minimized (e.g., the downsizing of the importance of hub cities. This allows us to assess the relational patterns in the lower rungs of the world city network in more detail (e.g., the flows between cities that have no direct airline connection, such as Kansas City and Zürich). Earlier air passenger data sets also covered only international flights, and had to be supplemented with data from particular countries in order to include flights among cities within countries. The MIDT data cover national and international flights; it provides truly transnational data.

With the cooperation of an airline, we were able to obtain a MIDT database that covers the period from January to August 2001 and contains information on more than 500 million passenger movements. This database was used to measure the total number of O/D passengers for US cities for the period under investigation. To achieve this, we relabelled the airport codes into city codes. This was necessary to compute meaningful measures because a number of cities have more than one major airport. Arraying the resulting data in an inflow-outflow matrix, we used formal network analysis (c.f., Borgatti, et al. 2002) to generate measures of "betweenness," indicating the relative position of each of our 57 U.S. cities within the worldwide hierarchy of cities. Cities with higher betweenness scores are more central to the global system of cities than those with lower scores. Hanneman and Riddle (2005), explain the concept of betweenness as follows: 
Betweenness: The third reason that actor A is advantaged in the ... network is because actor A lies between each other pairs of actors, and no other actors lie between $\mathrm{A}$ and other actors. If $\mathrm{A}$ wants to contact $\mathrm{F}$, A may simply do so. If $\mathrm{F}$ wants to contact B, they must do so by way of A. This gives actor A the capacity to broker contacts among other actors -- to extract "service charges" and to isolate actors or prevent contacts (in Chapter 10).

The cities in our analyses cover a wide range of the U.S. urban hierarchy, with betweeness scores ranging from 600.9 (Fresno) to 39,487.5 (New York).

Dependent variables. Our primary interest is in estimating the effects of GLOBAL on two different indicators of social polarization. We construct our dependent variables using U.S. Census data on (1) income, using the distribution of the households into the extremes of the national income distribution; and (2) occupations, using the distribution of service occupations into categories related to skill. We compute polarization measures for each. Income polarization is based on the balance of households concentrated in the highest and lowest quintiles of the national household income distribution ${ }^{2}$ :

$\mathrm{INCPOL}=(\mathrm{HINC}+\mathrm{LOINC})-\mathrm{ABS}(\mathrm{HINC}-\mathrm{LOINC})$

Where

INCPOL is the index of the extent to which the distribution of income is polarized HINC is the census estimate of the percentage of a city's adult population (or households) that is concentrated in the highest overall national income quintile. 
LOINC is the census estimate of the percentage of a city's adult population (or households) that is concentrated in the lowest quintile.

By taking the absolute difference between the high and low categories, our measures of polarization guards against mistaking mono-polarized distributions for true bipolarity. ${ }^{3}$

Again, income polarization is measured using census data that provide estimates of the percentages of households falling into each quintile of the national income distribution ${ }^{4}$. For example, these data include the percentage of each city's households that is at or above the national average for the highest income $20 \%$ of the population. We use this and the percentage of a city's households at or below the national lowest-earning quintile of families. Thus, these are relative measures of the income distribution, based on comparing each city to the national average. We use highest (HINC) and lowest income quintile (LOINC) estimates to produce an index of income polarization according to the formula above. Thus, cities are more polarized to the extent that their households fall relatively equally into the lowest and highest national quintiles of the household income distribution. For our cities, the income polarization scores range from .2078 (Washington) to .3984 (Miami). We also use estimates of overall inequality in some of our models, recognizing that this a more familiar measure of inequality ${ }^{5}$. However, we have no expectation about the correlation of our measure of polarization with the measure of overall inequality. Because the polarization measure is about both ends of the income distribution, it will not necessarily sort cities in the same way as the GINI. For example, the median-ranked cities in terms of polarization among our cities are San Diego and Baltimore (each with polarization scores of about .327). However, in terms of the GINI index they are ranked $20^{\text {th }}(\mathrm{GINI}=.448)$ and $37^{\text {th }}(.433)$, respectively. 
The world cities literature also discusses occupational polarization: the growth in highly skilled jobs in finance, insurance, real estate, and legal services for the global economy and the growth in low skilled jobs such as personal services, food services, and custodial occupations. Thus we also estimate models of occupational polarization, using data from the U.S. Census 2000 Summary File 3 (SF 3), aggregated for "urbanized areas." Occupational polarization (OCCPOL) is measured according to a formula comparable to that, above, where:

HISVC $=$ The percentage of a city's employed workers falling into the high-skilled occupational categories

and

LOSVC $=$ The percentage of a city's labor force employed in the low-skilled occupations.

In addition to estimating models that examine the effects of global centrality on polarization, we also examine its effects on the "high" and "low" components of each polarization measure. We do this to test for the possibility that the global cities thesis is "halfright." That is, more globally central cities may indeed have greater concentrations of employment in high-end service occupations but not in low-end service occupations, and vice versa. If so, this would be consistent with Hamnett's (1994) "professionalization" thesis, a critique of Sassen's line of reasoning.

Control variables. Given the important role of immigration in explanations of polarization in global cities, we include a control variable for immigration. Because most versions of the global city hypothesis focus on recent immigration, we include the percentage of 
the population that immigrated within the five years preceding the U.S. Census (1995-2000) as our measure (NEWIMGR). To test whether the effect of GLOBAL depends on the level of immigration in a city, we include an interaction term in the appropriate models (NEWIM*GLOBAL).

Outside of the global cities literature, variation in the degree of polarization across cities is not well-theorized. Thus, aside from Hamnett's "professionalization" thesis, the factors for which our analysis ought to control are not clearly identified in an empirical literature on crosscity polarization. Our analyses do, however, include several control variables that related research suggests are theoretically important in explaining polarization in cities or that are important to the way in which social scientists think about aggregate-level social inequality. For example, in testing for the effects of global city centrality on occupational polarization, we control for aspects of cities' population age distribution. Because school and college-age (including graduate school) residents are more likely than older workers to be employed in occupations quite different than those that they will hold after training or education, we control for the percentage of cities' populations that are in the age range of 17-28 (YOUNG).

When we estimate the effects of GLOBAL on income polarization, we use a measure of the income distribution that is based on the relationship of the city household income distribution to national averages. This requires that we take into account variation in the cost of living across cities. We do this by controlling for median rents (MEDRNT). This measure is comparable, given our regression models, to the quintile estimates of cities' relative income distributions produced by Berube and Tiffany (2004:18-20). That is, their estimates were based on national 
figures that are standardized on regional cost of living adjustments for each city based on housing costs estimates.

In order to take into account Hamnett's (1994) “professionalization” argument, we control for the possible effects of the percentage of the employed population in professional occupations (PROFSN). This measure is based on a broader set of "professional" occupational categories than HISVC because we are not trying to match it with the high-end producer services occupations that are the focus of Sassens's thesis. Because including PROFSN is redundant in the occupational polarization models, we do not include it there. Similarly, we include the level of education, measured as the percentage of the adult population with college degrees (COLLGE), in the models examining occupational polarization. Following the logic of the spatial mismatch argument (e.g., Downey, 2003), the degree of Black/White residential segregation should be associated with the low-income component of our bipolarization measure. An important part of this argument is that poor minority group members are residentially segregated in areas of the city that make it more difficult for them to find (and get to) work. We therefore include a measure of segregation in the model in order to control for such an effect on income polarization. Our measure of segregation (W-BSEG) uses dissimilarity index scores for urbanized areas available through the U.S. Census. The research by Volesho and Fullerton (2005), Dawkins, et al. (2005), and Madden (1996) suggests controlling for employment in government and manufacturing employment, both of which should ameliorate polarization by providing higher wages to lower skilled workers. Thus, where appropriate, the models include, respectively, SLGOV (employment in state and local government), FEDGOV (employment in federal government), and MFG\%, (employment in manufacturing sector). Finally, we include a 
dummy variable (SOUTH) for cities located in the South in order to control for the historical and cultural heritage of race and class polarization that characterizes Southern places. ${ }^{6}$

\section{Findings}

Table 1 presents the descriptive statistics and simple bivariate correlations for the variables in the analyses. There are a few descriptive findings worth discussing briefly. First, GLOBAL is more closely related to GINI inequality $(r=0.55)$ than polarization, $(r=0.02$ for income polarization and $\mathrm{r}=0.16$ for occupational polarization). Moreover, the bivariate correlations suggest that GLOBAL is associated with higher proportions of the population in the top categories of income $(r=0.59)$ and service occupations $(r=0.19)$, but with lower shares of the population in bottom categories of income $(r=-.20)$ and service occupations $(r=-0.07)$. Thus, more globally central cities might have more inequality associated with relatively larger shares of the population in the top income and occupational categories, but we do not find correlational evidence to support the hypothesis that more globally central cities have relatively high shares of their populations in both the top and bottom of their income or occupational distributions, which would be indicative of polarization. Second, our outcome measures allow a conceptually broad test of the world city-polarization hypothesis, as they are not strongly correlated with each other. GINI inequality is only moderately correlated with income polarization $(r=0.36)$ and it is particularly distinct from occupational polarization $(r=-0.09)$. Similarly, the two measures of polarization are themselves conceptually distinct from one another, as they are inversely related $(\mathrm{r}=-0.19)$. Of course, while the simple correlations are suggestive, adequate tests of the global city thesis require multivariate analysis. 


\section{[TABLE 1 ABOUT HERE]}

Using OLS regression, we estimate the effect of cities' degree of global centrality on various measures of income and occupational distributions, net of the control variables. Table 2 presents results for the analysis of income polarization and inequality, and Table 3 presents results for the analysis of occupational polarization. Overall, the key finding is that we find mixed empirical support for the global city hypothesis. On the one hand, we do not find strong evidence that centrality is associated with higher levels of income polarization or occupational polarization, nor does it affect the components of income and occupational polarization. On the other hand, the results demonstrate that the effect of GLOBAL on income polarization depends on the level of immigration, which supports the notion that the polarizing effects of centrality are conditioned by larger influxes of immigrants into more global cities, a key tenet of Sassen's version of the global city hypothesis. Moreover, the results show that GLOBAL is associated with higher levels of GINI inequality. We detail these findings below. ${ }^{7}$

Model 1 (Table 2) estimates the effect of GLOBAL on income polarization, net of controls. GLOBAL does not have an effect on income polarization, although the sign is positive, which would be consistent with the global city hypothesis. To assess more specifically whether GLOBAL affects income polarization, we estimate models of the high income quintiles and low income quintiles (Models 2 and 3, respectively). Again, the coefficient for GLOBAL is positive, but it is not statistically significant. We then test for whether the effect of global centrality depends on the level of immigration in Model 4 by including an interaction term (GLOBAL*NEWIM). Here we find evidence that centrality and immigration combine to 
exacerbate income polarization, as the coefficient for the interaction term is positive and significant $(\mathrm{p}<0.01)$. That is, it appears that global centrality, by itself, is not associated with income polarization, but instead, global centrality coalesces with immigration to produce more highly polarized income distributions. This is an important and theoretically interesting finding that is consistent with Sassen's version of the global city hypothesis but has not been empirically documented in a multivariate analysis. Finally, we estimate the effect of GLOBAL on GINI inequality in Model 5 to assess whether GLOBAL behaves differently on income polarization and inequality. We find that GLOBAL is positively associated with GINI inequality, net of all controls. This finding, too, is theoretically interesting, given our null findings for income polarization in Models 1-3. It appears that more globally central cities have higher levels of GINI inequality. However, again, this is a measure of the unevenness in the distribution of households into national income quintiles. Also noteworthy, we find evidence that immigration is positively associated with GINI inequality.

\section{[TABLE 2 ABOUT HERE]}

Hamnett's (1994) critique of Sassen argues that she mistakes polarization for professionalization in global cities. Thus, we include the percent of the labor force in professional occupations in these models. ${ }^{8}$ Model 1 indicates that, contrary to the professionalization thesis, professionalization has a negative effect on income polarization. Moving to Models 2 and 3, It appears that professionalization is associated with higher proportions of the population in the high income quintiles, and lower proportions of the population in the low income quintiles, which suggests that professionalization results in higher median incomes in cities (independently of cost of living differences), but not income 
polarization, per se. This finding also casts doubt on the assumption in Sassen's version of the global city-polarization thesis suggesting that higher wage-levels associated with professional occupations generate a larger low-wage sector. We also find that Black-White residential segregation exacerbates both income polarization and overall inequality (Models 2.1, 2.4, and 2.5). It is not far-fetched to suppose that both income polarization and overall inequality in American cities are largely racialized matters, as suggested in Abu-Lughod's critique (1999) of the global city hypothesis based on her study of New York, Chicago, and Los Angeles. Surprisingly, our control measure for the percentage of the labor force employed in state and local government has a positive effect on income polarization. This variable is not welltheorized in the cross-city literature on inequality, but we expected government employment to work against income polarization by increasing opportunities to attain middle incomes. Instead, we find that cities with higher shares of the population employed in state and local government also have levels of income polarization (Model 1) associated with a smaller high income population segment (Model 2), and a higher low income segment (Model 3). At the same time, the relative size of federal workers as a share of the labor force has no significant effects in any of these models. Our estimate of the relative cost of living was not significantly associated with income polarization, but its strong effect on the relative size of the top and bottom income quintiles (in the expected directions) indicates that it is, indeed, an important factor to control in these models. In general, our models fit the data relatively well, with adjusted $\mathrm{R}^{2}$ measures ranging from 0.35 to 0.85 .

As a sensitivity test, and to further test the professionalization thesis, we estimate models of occupational polarization and present the results in Table 3. Again, we do not find empirical 
evidence that GLOBAL is associated with occupational polarization: the coefficient is not statistically significant in any of the models. As we did in the analysis of income polarization, we estimate models on the high and low ends of the distribution for occupational polarization (Models 2 and 3). Neither of the models demonstrates that GLOBAL affects the relative sizes of either the professional labor force or the low-skilled service labor force. In Model 4, we include an interaction term for GLOBAL*NEWIM to test whether the effect of GLOBAL might depend on the level of immigration, but again, the coefficient for the interaction term is not significant.

\section{[TABLE 3 ABOUT HERE]}

The percentage of the population that is college-educated is positively associated with occupational polarization (Model 1), raising the proportion of the population in the professional service labor force (Model 2) and lowering the proportion of the population in the low-skilled service labor force (Model 3). No other variables have consistently significant effects on occupational polarization, and with the exception of Model 2, the explained variance is lower relative to our models for income polarization, suggesting the need for more theorization of cross-city variation in occupational polarization. The degree of Black-White residential segregation increases occupational polarization (Models 1 and 4). The size of the manufacturing sector lowers the share of the workforce in both high-end services and low-end services (Models 2 and 3), but it does not affect occupational polarization. Immigration and the population age structure have no bearing on occupational polarization. ${ }^{9}$

\section{Conclusions}

The literature on "world cities" and "global cities" is extensive and growing. It consists of conceptual treatises aimed at refining the key concepts, empirical efforts to classify the 
world's cities, and research that specifies the global hierarchy of cities. This literature also includes theoretical claims about the consequences of world city status for social structural patterns within cities. While this subset of the literature is often illustrated by examples from specific cities, these examples are not usually marshaled systematically.

This paper provides a systematic, empirical assessment of a central hypothesis of the global cities literature. Using a measure of cities' position in the global city hierarchy for 57 U.S. cities, we tested the hypothesis that cities "higher up" in this hierarchy are more likely to be more socially polarized. Our findings do not provide strong support for the predicted positive effects of global centrality on the degree to which a city is socially polarized. While our measure of a city's global centrality is positively related to overall inequality in the distribution of households into national income quintiles, it is related to polarization only in the context of higher levels of recent immigration. These findings support some of the theorization about global cities and world cities detailed by John Friedmann and Saskia Sassen. They are especially interesting in light of Sassen's focus on the role of immigration in transmitting globalization's putative polarizing effects on the top cities in the world system's city system. At the same time, Sassen's work is far more explicit about the effects of global city status on occupational polarization, full as it is of vivid examples of jobs as dog walkers and highly paid producer service professionals both being generated by the global city's role as a site for high-end "producer services." Obviously our data do not compel us to dismiss this global city hypothesis, but nor do they allow us to claim enthusiastic support for it. Instead, they indicate that we should be cautious in our claims; the global city story is a nuanced one. 
As a first step in what is becoming a growing body of research, our study is not without cautions and caveats. The usual suspects are involved: data and measurement. First, the world city-polarization thesis is about cities internationally, and we have examined only U.S. cities. Here, we are limited by data availability and access. At this point, we can obtain measures of the income and occupational distributions, and the most important control variables, only for cities in the United States. Obviously, this limits the generalizability of our findings, and it means that we have provided a restricted test of the polarization thesis. Another important caveat is that we measure cities' relative position in the global hierarchy in terms of the flows of air travelers between pairs of cities. There are other measures of world city network position that may provide different results because they emphasize different notions of what it means to be a "world city." For example, Taylor and his GaWC associates identify a city's prominence in the world city network on the basis of only the largest producer services firms, and Alderson and Beckfield measure centrality in terms of Fortune 500 corporations. In fact, the GaWC network is based on firm-city relations, ranking cities in terms of how important they are as locations of headquarters of producer services firms and as locations of three levels of decreasingly important branch offices. We use the MIDT measure because it has more coverage of cities in the United States. While the Alderson and Beckfield data would allow more coverage, a number of U.S. cities that they identify as globally prominent have low face validity as world cities (e.g., Omaha), ranking high only because they are home to one very significant global firm headquarters. Moreover, some of their "cities" are embedded within larger urbanized areas and are too small geographically to encompass the polarization processes on which we focus. 
Two avenues for future research seem especially fruitful on the basis of our findings. One avenue will be to further explore the relationships between international migration, globalization, and global city processes. International migration has been overlooked as a key global-level dynamic, as scholars have devoted more efforts on other important factors, including trade relations and movements of investment capital. Yet we demonstrate that international migration works with global dynamics, in this case global centrality, to produce higher levels of social polarization and inequality in U.S cities. International migration can be investigated at the national level, but cities are particularly well suited for systematic study of the types of processes that drive contemporary global social change because these processes are often centered on urban areas; because the majority of the world's population is now urban; and most importantly, because global social processes occur at levels above and below the nation-state. Thus, we need to better understand how global processes are associated with international migrations directed toward urban areas. Specifically, studies that examine the relationship between cities' global centrality and immigration rates are particularly warranted on the basis of our findings.

A second avenue will be to expand the coverage of cases to include cities in other countries. Obviously, this requires that we begin to build an international database of cities that goes beyond indexing cities' with respect to the global urban hierarchy, their population sizes, or other such attributes. Previous studies of what it means for urban residents to live in a global city have relied on case studies or limited comparative case studies, only a few of which have been deliberately systematic. Such studies have certain advantages over quantitative studies such as ours. However, those advantages do not include careful, systematic tests of the hypothesized relationships found in the world cities literature. 
As a final note, while the practical significance of research on the effects of global city status on urban life might seem limited, it is clear that powerful interests operating within cities, and within nations on "behalf" of particular cities, frequently mobilize global city rhetoric to marshal support (often in the form of public expenditures) for efforts to push "their" cities up the global hierarchy. We believe it is worthwhile trying to understand some of the social consequences that may follow from these efforts.

\section{References:}

Abu-Lughod, J.L. 1995. "Comparing Chicago, New York and Los Angeles: Testing Some World Cities Hypotheses," in P.L. Knox and P.J. Taylor, eds., World Cities in a World System, pp. 171-191. New York: Cambridge University Press.

Abu -Lugod, Janet 1999. America's Global Cities. Minneapolis: University of Minnesota Press.

Alderson, A. and Beckfield, J. 2004. "Power and position in the world city system," American Journal of Sociology 109, 811-851.

Alderson, A., Beckfield, J, Sprague-Jones, J. 2010. Inter-city relations and globalization: The evolution of the global urban hierarchy, 1981-2007, Urban Studies 47 (9): 1899-1923.

Alderson, A. and Nielsen, F. 1999. "Income inequality, development, and dependence: A reconsideration," American Sociological Review 64 (4): 606-631.

Alderson, Arthur and Nielsen, F. 2002. "Globalization and the great U-turn: Income inequality trends in 16 OECD countries," American Journal of Sociology, 107, 1244-1299. 
Autor, D. H., Katz, L. F. and Kearney, M.S. 2006. "The polarization of the U.S. labor market." American Economic Review 96, 189-194.

Berube, A. and Tiffany T. 2004. "The shape of the curve: Household income distributions in US cities, 1979-1999.” August; The Living Cities Series. Washington, DC, The Brookings Institution.

Borgatti, S., Everett, M., and Freeman, L. 2002. Ucinet for Windows: Software for Social Network Analysis. Harvard: Analytic Technologies.

Burgers, J. and Musterd, S. 2002. "Understanding urban inequality: A model based on existing theories and an empirical illustration." International Journal of Urban and Regional Research 26, 403-413.

Cox, R. and Watt, P. 2002. "Globalization, polarization and the informal sector: The case of paid domestic workers in London," Area 34, 39-47.

Dawkins, C. J., Shen, Q., and Sanchez, T.W. 2005. "Race, space, and unemployment duration." Journal of Urban Economics, 58, 91-113.

Derudder B., Taylor P.J., Witlox F. \& Catalano G. 2003. Hierarchical tendencies and regional patterns in the world city network: A global urban analysis of 234 cities. Regional Studies 37, 875-886.

Derudder, B., Witlox, F. 2005, “An appraisal of the use of airline data in assessing the world city network: a research note on data." Urban Studies, 42: 2371-2388.

Derudder, B. and Witlox, F. 2008. "Mapping global city networks through airline flows: context, relevance, and problems.” Journal of Transport Geography, 16, 305-312. Derudder, B., Timberlake, M. and Witlox, F. (eds.). 2010, The Changing Configuration of the 
World City Network. Urban Studies special issue, 47.

Downey, L. 2003. "Spatial measurement, geography, and urban racial inequality." Social Forces, 81, 937-952.

Friedmann, J. 1986. "The world city hypothesis." Development and Change 17, 69-84.

Friedmann, J. 1995. "Where we stand: A decade of world city research." in Knox, P. L. and Taylor P. J. (eds.), World Cities in a World-System, pp. 21-47. Cambridge: Cambridge University Press.

Friedmann, J. 2001. "World cities revisited: A comment." Urban Studies 38, 2535-2536.

Goos, M., Manning, A., and Solomons, A. 2009. "Job polarization in Europe," American Economic Review: Papers \& Proceedings, 99, 58-63.

Hall, P. 1966. The World Cities._Heinemann, London.

Hamnett, C. 1994. "Social polarization in global cities: Theory and evidence," Urban Studies 31, 401-424.

Hamnett, C. 1996. "Social polarisation, economic restructuring and welfare state regimes," Urban Studies 33, 1407-1430.

Hanneman, R and Riddle, M. 2005. "Centrality and Power," Chapter 10 in Introduction to Social Network Methods. Riverside, CA: University of California, Riverside (Published in digital form at http://faculty.ucr.edu/ hanneman/).

Hill, R., Fujita, K. 2000. "State restructuring and local power in Japan," Urban Studies 37, 67390.

Hill, R. 2000. "Global cities and developmental states: New York, Tokyo and Seoul," Urban Studies 37, 2167 - 2195. 
Knox, P. and Taylor, P. (eds.). 1995. World Cities in a World-System, New York: Cambridge University Press.

Lemieux, T. 2008. "The changing nature of wage inequality," Journal of Population Economics $21,21-48$.

Levine, M. V. 1995. "Globalization and wage polarization in U.S. and Canadian cities: Does public policy make a difference?" in P. Kresl and G. Gappert (eds.), North American Cities and the Global Economy: Challenges and Opportunities, pp. 89-111. Thousand Oaks, CA: Sage Publications.

Ma, Xiulian and Michael Timberlake. 2008. "Identifying China's Leading World City: A Network Approach." GeoJournal 71:19-35.

Madden, J.F., 1996. "Changes in the distribution of poverty across and within the U.S. metropolitan areas, 1979- 89," Urban Studies, 33, 1581-1600.

M. Mahutga, X. Ma, D. Smith and M. Timberlake. 2010. "Economic Globalization and the Structure of the World-City System: The Case of Airline Passenger Data". Urban Studies, vol. 47(9): 1925-1947.

Matthiessen, C., Winkel Schwarz, A., Find, S. (2010) World Cities of Scientific Knowledge: Systems, Networks and potential dynamics. An analysis based on bibliometric indicators, Urban Studies, August 47 (9): 1879-1927.

Miller, W. H. 1999. “Airlines take to the internet.” Industry Week, 248, 130-134.

Neal, Z. 2008. "The duality of world cities and firms: comparing networks, hierarchies, and inequalities in the global economy," Global Networks 8, 94-115.

Neal, Z. 2011. "From central places to network bases: A transition in the U.S. urban hierarchy, 
1900-2000," City and Community 10, 49-75.

Nørgaard, H. 2003. "The Global city thesis: social polarization and changes in the distribution of wages," Geografiska Annaler: Series B, Human Geography_85, 103-119.

Sanderson, M., and Kentor, J. 2008. "Foreign direct investment and international migration: A cross-national analysis of less-developed countries.” International Sociology 23, 514539.

Sanderson, M., and Kentor, J. 2009. "Globalization, development, and international migration: A cross-national analysis, 1970-2000." Social Forces 88, 301-336.

Sassen, S. 1985. "Capital mobility and labor migration: Their expression in core cities," Chapter 11 in M. Timberlake, (ed.), Urbanization in the World Economy, pp. 231-265. Orlando: Academic Press.

Sassen, S. 1988. The Mobility of Labour and Capital: A Study in International Investment and Labor Flow. Cambridge: Cambridge University Press.

Sassen, S. 1991. The Global City: New York, London, Tokyo. Princeton: Princeton University Press.

Sassen, S. 1998. Globalization and Its Discontents: Essays on the New Mobility of People and Money. New York: New Press.

Sassen, S. 2001. The Global City. Second Edition. Princeton: Princeton University Press.

Sassen, S. 2006. Cities in a World Economy, Third Edition. Thousand Oaks: Pine Forge.

Sassen, S. 2007. A Sociology of Globalization. New York: Norton.

Sassen, S. 2008. “Two stops in today’s new global geographies: Shaping novel labor supplies and employment regimes." American Behavioral Scientist 52, 457-496. 
Sassen, S. 2009. "Cities today: A new frontier for major developments." Annals of the American Association of Political and Social Science 626, 53-71.

Savitch, H. V. 2002. “The globalisation process,” in R. Hambleton, H. Savitch, and M.

Stewart (eds.), Globalism and Local Democracy: Challenge and Change in Europe and North America, pp. 19-29. Basingstoke: Palgrave.

Shin, K.H. and M. Timberlake. 2000. "World cities in Asia: cliques, centrality and connectedness." Urban Studies, vol. 37(12): 2257-2285.

Smith, D.A. and Timberlake M. 1995a. "Cities in Global Matrices: Toward Mapping the WorldSystem's City-System." Pp. 79-97 in World Cities in a World-System, edited by P. L. Knox and P. J. Taylor. New York: Cambridge University Press. 1995b. "Conceptualizing and mapping the structure of the world system's city system." Urban Studies 32, 287-302.

Smith, D, and Timberlake. M. 2001. "World City Networks and Hierarchies, 1977-1997: an Empirical Analysis of Global Air Travel Links.” American Behavioral Scientist 44: $1656-78$.

Taylor, P. 2004. World City Network: A Global City Analyses. London and New York: Routeledge.

Taylor, P., Catalano, P., and Walker, D. 2002. "Measurement of the world-city network." Urban Studies 39, 2367-2394.

Taylor, P., P. Ni, B. Derudder, M. Hoyler, J. Huang, and F. Witlox. 2011. Global Urban Analysis: A Survey of Cities in Globalization. London, Earthscan.

Vaattovaara, M. and Kortteinen M. 2003. "Beyond polarisation versus professionalisation? A 
case study of the development of the Helsinki Region, Finland," Urban Studies 40, 2127 2145.

Vinciguerra, S., Frenken, K., Valente, M. (2010) The geography of internet infrastructure: an evolutionary simulation approach based on preferential attachment, Urban Studies, August 47 (9): 1969-1984.

Volscho, T. Jr. and Fullerton, A. S. 2005. "Metropolitan earnings inequality: union and government-sector employment effects,” Social Science Quarterly, Supplement to vol. $86,1324-1327$.

Walks, R. 2001. "The social ecology of the post-fordist/global city? Economic restructuring and socio-spatial polarisation in the Toronto urban region," Urban Studies_38, 407-447. 
Table 1. Bivariate Correlations and Descriptive Statistics

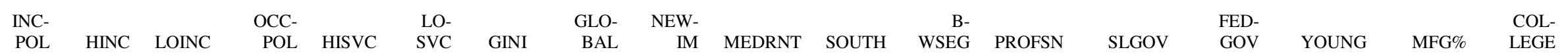

INCPOL

$\begin{array}{rrrrrr}\text { HINC } & -0.39 & & & & \\ \text { LOINC } & 0.49 & -0.77 & & & \\ \text { OCCPOL } & -0.19 & 0.19 & -0.29 & & \\ \text { HISVC } & -0.55 & 0.57 & -0.53 & 0.42 & \\ \text { LOSVC } & 0.04 & -0.19 & 0.10 & -0.41 & -0.40 \\ \text { GINI } & 0.36 & -0.08 & 0.57 & -0.09 & -0.21\end{array}$

$\begin{array}{llllllll}\text { GLOBAL } & 0.02 & 0.59 & -0.20 & 0.16 & 0.19 & -0.07 & 0.55\end{array}$

$\begin{array}{lllllllll}\text { NEWIM } & -0.12 & 0.51 & -0.27 & -0.09 & 0.07 & 0.14 & 0.38 & 0.72\end{array}$

$\begin{array}{llllllllll}\text { MEDRNT } & -0.32 & 0.82 & -0.67 & 0.11 & 0.43 & 0.12 & 0.00 & 0.59 & 0.72\end{array}$

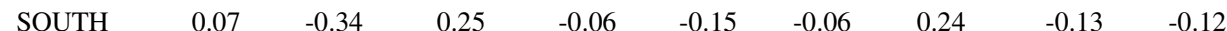

$\begin{array}{llllllllll}\text { B-WSEG } & 0.33 & 0.04 & 0.21 & 0.35 & -0.06 & -0.28 & 0.33 & 0.22 & -0.27\end{array}$

$\begin{array}{llllllllll}\text { PROFSN } & -0.42 & 0.77 & -0.56 & 0.50 & 0.82 & -0.51 & -0.12 & 0.37 & 0.21\end{array}$

$\begin{array}{llllllllll}\text { SLGOV } & 0.08 & -0.04 & 0.13 & -0.16 & 0.16 & -0.14 & -0.13 & -0.15 & 0.03\end{array}$

$\begin{array}{llllllllll}\text { FEDGOV } & -0.23 & 0.11 & -0.14 & -0.10 & 0.14 & 0.17 & -0.28 & -0.06 & -0.06\end{array}$

$\begin{array}{llllllllll}\text { YOUNG } & -0.25 & 0.01 & -0.20 & -0.05 & 0.11 & -0.07 & -0.17 & -0.10 & 0.23\end{array}$

$\begin{array}{llllllllll}\mathrm{MFG} \% & 0.27 & -0.01 & -0.02 & 0.25 & -0.11 & -0.33 & -0.08 & -0.12 & -0.31\end{array}$

$\begin{array}{llllllllll}\text { COLLEGE } & -0.54 & 0.82 & -0.70 & 0.49 & 0.82 & -0.42 & -0.18 & 0.39 & 0.30\end{array}$

$\begin{array}{rrrrrrrrrr}\text { Mean } & 0.33 & 0.22 & 0.18 & 0.19 & 0.11 & 0.11 & 44.17 & 5901.75 & 4.6 \\ \text { Std. Dev. } & 0.04 & 0.05 & 0.03 & 0.02 & 0.03 & 0.02 & 1.97 & 7348.8 & 3.07 \\ \text { Skew } & -0.41 & 0.85 & 0.42 & -1.51 & 0.43 & 2.72 & 0.98 & 2.51 & 0.91\end{array}$

$\begin{array}{rrrr}-0.21 & & & \\ -0.31 & -0.09 & & \\ 0.56 & -0.20 & 0.10 & \\ 0.04 & -0.10 & -0.25 & 0.20 \\ 0.17 & 0.03 & -0.26 & 0.14 \\ 0.17 & 0.23 & -0.55 & 0.06 \\ -0.29 & -0.15 & 0.46 & -0.01 \\ 0.65 & -0.17 & -0.02 & 0.95 \\ & & & \\ 626.11 & 0.37 & 0.6 & 35.29 \\ 95.66 & 0.49 & 0.11 & 4.11 \\ 0.69 & 0.55 & -0.29 & 0.75\end{array}$

$\begin{array}{rr}0.00 & \\ 0.18 & 0.10 \\ -0.24 & -0.40 \\ 0.09 & 0.10 \\ & \\ 11.44 & 4.08 \\ 3.42 & 3.82 \\ 2.14 & 2.73\end{array}$

$\begin{array}{rrr}0.18 & 11.64 & 26.92 \\ 0.02 & 4.6 & 5.17 \\ 0.84 & 0.53 & 0.72\end{array}$


Table 2. OLS Regression of Income Polarization and GINI Inequality on Global Centrality, 2000

\begin{tabular}{|c|c|c|c|c|c|}
\hline & (1) & (2) & (3) & (4) & (5) \\
\hline & INCPOL & HINC & LOINC & INCPOL & GINI \\
\hline \multirow[t]{3}{*}{ GLOBAL } & $1.6 \mathrm{e}-04$ & $2.5 \mathrm{e}-06$ & $1.2 \mathrm{e}-05$ & $-2.5 e-05$ & $1.4 \mathrm{e}-03^{* *}$ \\
\hline & $(1.35)$ & $(0.35)$ & $(1.55)$ & $(-1.36)$ & $(3.02)$ \\
\hline & {$[0.29]$} & {$[0.04]$} & {$[0.26]$} & {$[-0.46]$} & {$[0.54]$} \\
\hline \multirow[t]{3}{*}{ NEWIM } & -0.002 & -0.0002 & 0.002 & -0.004 & $0.223+$ \\
\hline & $(-0.79)$ & $(-0.13)$ & (1.09) & $(-1.30)$ & $(1.82)$ \\
\hline & {$[-0.18]$} & {$[-0.01]$} & [0.19] & {$[-0.29]$} & {$[0.35]$} \\
\hline \multirow[t]{3}{*}{ MEDRNT } & $5.6 \mathrm{e}-04$ & $0.0003 * * *$ & $-0.0003^{* * *} *$ & 0.0001 & -0.006 \\
\hline & $(0.62)$ & $(5.55)$ & $(-4.23)$ & (1.19) & $(-1.63)$ \\
\hline & {$[0.14]$} & {$[0.58]$} & {$[-0.71]$} & {$[0.25]$} & {$[-0.30]$} \\
\hline \multirow[t]{3}{*}{ SOUTH } & 0.005 & $-0.014 *$ & 0.009 & 0.003 & $1.173^{* *}$ \\
\hline & $(0.50)$ & $(-2.39)$ & (1.47) & $(0.30)$ & (3.09) \\
\hline & [0.06] & {$[-0.13]$} & {$[0.13]$} & [0.03] & [0.29] \\
\hline \multirow[t]{3}{*}{ B-WSEG } & $0.144 *$ & 0.049 & 0.041 & $0.130^{*}$ & $4.547+$ \\
\hline & $(2.48)$ & (1.37) & (1.07) & $(2.38)$ & (1.91) \\
\hline & {$[0.41]$} & [0.11] & {$[0.14]$} & {$[0.37]$} & {$[0.26]$} \\
\hline \multirow[t]{3}{*}{ PROFSN } & $-0.006^{* * *}$ & $0.005^{* * *}$ & $-0.003^{* *}$ & $-0.006^{* * *}$ & -0.099 \\
\hline & $(-4.22)$ & (5.68) & $(-3.05)$ & $(-3.71)$ & $(-1.60)$ \\
\hline & {$[-0.66]$} & {$[0.43]$} & {$[-0.37]$} & {$[-0.56]$} & {$[-0.21]$} \\
\hline \multirow[t]{3}{*}{ SLGOV } & $0.004 * *$ & $-0.002 *$ & $0.003 * *$ & $0.003 *$ & 0.056 \\
\hline & (3.02) & $(-2.26)$ & $(3.45)$ & $(2.12)$ & $(0.97)$ \\
\hline & {$[0.37]$} & {$[-0.13]$} & {$[0.32]$} & {$[0.25]$} & [0.10] \\
\hline \multirow[t]{3}{*}{ FEDGOV } & -0.001 & -0.0003 & 0.001 & -0.001 & -0.047 \\
\hline & $(-0.40)$ & $(-0.35)$ & $(1.02)$ & $(-0.80)$ & $(-0.93)$ \\
\hline & {$[-0.05]$} & {$[-0.02]$} & [0.09] & {$[-0.09]$} & {$[-0.09]$} \\
\hline \multirow[t]{3}{*}{$\begin{array}{l}\text { NEWIM* } \\
\text { GLOBAL }\end{array}$} & & & & $0.001 * *$ & \\
\hline & & & & $(2.74)$ & \\
\hline & & & & {$[0.78]$} & \\
\hline \multirow[t]{2}{*}{ Constant } & $0.384 * * *$ & $-0.167 * * *$ & $0.363^{* * *}$ & $0.374 * * *$ & $46.04^{* * * *}$ \\
\hline & $(5.83)$ & $(-4.08)$ & $(8.27)$ & $(6.02)$ & $(17.03)$ \\
\hline $\mathrm{N}$ & 57 & 57 & 57 & 57 & 57 \\
\hline $\mathrm{R}$-sq & 0.45 & 0.87 & 0.67 & 0.52 & 0.62 \\
\hline adj. R-sq & 0.35 & 0.85 & 0.62 & 0.43 & 0.56 \\
\hline
\end{tabular}




\begin{tabular}{|c|c|c|c|c|}
\hline & (1) & (2) & (3) & (4) \\
\hline & OCCPOL & HISRV & LOWSRV & OCCPOL \\
\hline \multirow[t]{3}{*}{ GLOBAL } & $-8.12 \mathrm{e}-09$ & $-4.70 \mathrm{e}-05$ & $-1.9 \mathrm{e}-06$ & $-1.3 \mathrm{e}-06$ \\
\hline & $(-0.01)$ & $(-1.16)$ & $(-0.31)$ & $(-0.09)$ \\
\hline & {$[-0.001]$.} & {$[-0.12]$} & {$[-0.07]$} & {$[-0.04]$} \\
\hline \multirow[t]{3}{*}{ NEWIM } & -0.0001 & -0.0004 & 0.0017 & -0.0011 \\
\hline & $(-0.67)$ & $(-0.44)$ & $(1.21)$ & $(-0.65)$ \\
\hline & {$[-0.14]$} & {$[-0.04]$} & {$[0.26]$} & {$[-0.15]$} \\
\hline \multirow[t]{3}{*}{ COLLEGE } & $0.0023^{* *}$ & $0.0051^{* * *}$ & $-0.0019 * * *$ & $0.0023^{* *}$ \\
\hline & $(4.27)$ & (15.11) & $(-3.84)$ & (3.99) \\
\hline & {$[0.54]$} & [0.91] & {$[-0.49]$} & {$[0.55]$} \\
\hline \multirow[t]{3}{*}{ SOUTH } & 0.0019 & 0.0029 & -0.005 & 0.002 \\
\hline & $(0.37)$ & $(0.85)$ & $(-1.02)$ & $(0.36)$ \\
\hline & [0.04] & [0.05] & {$[-0.12]$} & {$[0.04]$} \\
\hline \multirow[t]{3}{*}{ B-WSEG } & $0.0611+$ & 0.016 & -0.034 & $0.061+$ \\
\hline & (1.83) & $(0.75)$ & $(-1.06)$ & $(1.80)$ \\
\hline & [0.32] & [0.07] & {$[-0.19]$} & {$[0.32]$} \\
\hline \multirow[t]{3}{*}{ YOUNG } & 0.076 & -0.022 & -0.160 & 0.075 \\
\hline & $(0.44)$ & $(-0.19)$ & $(-0.97)$ & $(0.43)$ \\
\hline & {$[0.06]$} & [0.02] & {$[-0.14]$} & {$[0.06]$} \\
\hline \multirow[t]{3}{*}{$\mathrm{MFG} \%$} & 0.0004 & $-0.0009^{*}$ & $-0.0011+$ & 0.0004 \\
\hline & $(0.71)$ & $(-2.24)$ & $(-1.78)$ & $(0.70)$ \\
\hline & [0.09] & {$[-0.15]$} & {$[-0.24]$} & [0.09] \\
\hline \multirow[t]{3}{*}{ GLOBAL*NEWIM } & & & & $1.2 \mathrm{e}-07$ \\
\hline & & & & $(0.09)$ \\
\hline & & & & {$[0.05]$} \\
\hline \multirow[t]{2}{*}{ Constant } & $0.074+$ & -0.022 & $0.217 * * *$ & $0.073+$ \\
\hline & $(1.77)$ & $(-0.81)$ & $(5.45)$ & $(1.76)$ \\
\hline $\mathrm{N}$ & 57 & 57 & 57 & 57 \\
\hline R-sq & 0.41 & 0.85 & 0.40 & 0.41 \\
\hline Adj. R-sq & 0.32 & 0.83 & 0.32 & 0.31 \\
\hline
\end{tabular}


${ }^{1}$ We also conducted a comparable exercise using a measure of educational polarization with similar results to those for occupational polarization (shown in Table 3). They are available upon request.

${ }^{2}$ Our operationalization of polarization could be more appropriately termed "bi-polarization", which for the sake of simplicity we avoid using. Bi-polarization is the appropriate operationalization of the hypothesized social structural effects of world city centrality, according to the literature that has inspired this effort.

${ }^{3}$ For example, without taking into account the absolute difference between the relative concentration in the high and low categories, City A in which the low percentile was $10 \%$ and the top percentile was $40 \%$ would have the same score as City B in which the high and low percentiles each had 25\%. Clearly City B is "bi-polar" in a manner consistent with the polarization hypothesis, and City A is not. Our measure gives City A a polarization score of 20 and City B a score of 50.

${ }^{4}$ Direct measures of the income distribution are not available from Census for all of the cities in this study. This leaves us with an unconventional income distribution measure, but it seems to us to be justifiable measure of one aspect of polarization for our purpose of comparing cities in terms of the concentration of residents in bottom and top of the income distribution. That is, we have a measure of bi-polarization at the city level that is standardized by the overall national income distribution. 
${ }^{5}$ Again, this is based on the income distribution data available for our cities: the distribution of household percentages into the national quintile distribution. Thus our GINI measures inequality for cities relative to the national distribution in income.

${ }^{6} \mathrm{We}$ also controlled for population size (results not shown, but available upon request) to account for the possible confounding effect of population on polarization. Including population size in the models does not change the substantive results we report here. Moreover, population size was an insignificant explanation of polarization, which is consistent with Neal's (2011) study that reports a "decoupling" of population size from other indicators of global centrality among U.S. cities beginning in about 1940 and continuing to the present.

${ }^{7}$ We tested for whether spatial autocorrelation was present in our key dependent variables (Income polarization and Occupational polarization) using Moran's I. The data were geocoded using latitude and longitude values for the central city. There is no evidence of spatial autocorrelation in these variables so we do not correct the standard errors for spatial autocorrelation.

${ }^{8}$ Moreover, in Table 3, we provide a direct test of Hamnett's (1994) critique by estimating the effects of GLOBAL on employment in high-end services.

${ }^{9}$ We have more regression results available that will provide further confidence in the results we present in the paper and we are glad to make these available upon request. 